\title{
PENGARUH PERLAKUAN SUHU YANG BERBEDA TERHADAP WAKTU PENETASAN, DAYA TETAS TELUR DAN TINGKAT KELANGSUNGAN HIDUP LARVA IKAN BRUSHMOUTH ALBINO (Ancistrus cirrhosus)
}

\section{THE EFFECT OF TEMPERATURE ON HATCHING TIME, HATCHING RATE AND LARVAE SURVIVAL RATE IN BRITTLENOSE CATFISH ALBINO (Ancistrus cirrhosus)}

\author{
Dinna Yuliani ${ }^{1}$, Fia Sri Mumpuni ${ }^{2}$, Muarif ${ }^{2}$ \\ ${ }^{1}$ Sekolah Vokasi, IPB University Bogor \\ ${ }^{2}$ Program Studi Akuakultur, Fakultas Pertanian, Universitas Djuanda Bogor \\ J1. Tol Ciawi 1, Pos 35 Bogor 16720 \\ Email: dinnayuliani03@gmail.com
}

\begin{abstract}
The aim of this study was to determine the effect of different incubation temperature on hatching time, hatching rate and larvae survival rate in brittlenose catfish albino Ancistrus cirrhosus eggs. A completely randomized design is used in this study with 3 different treatments and 3 replications. The treatments were; A as a control which room temperature had used $\left(25-26^{\circ} \mathrm{C}\right)$, B $28^{\circ} \mathrm{C}$ and C $31^{\circ} \mathrm{C}$. Based on the result at Least Significant Different (LSD) test $(\mathrm{P}<0,05)$, treatment $\mathrm{C}$ hatch at 92,23 hours ( 3 days 20 hours) and $\mathrm{B}$ hatch at 93,29 hours (3 days 21 hours) had not significantly different in between, except A which hatch at 95,50 hours (3 days 23 hours) had sicnificantly different with those both treatments. The hatching rate at LSD test result showed all treatments were significantly different which A was the highest hatching rate 95,96\% and $\mathrm{C}$ had the lowest $66,67 \%$. Based on ANOVA test, survival rate of larvae had not significantly different between treatments $(\mathrm{P}<0,05)$.
\end{abstract}

Keywords: brittlenose catfish albino, temperature, egg

\begin{abstract}
ABSTRAK
Penelitian ini dilaksanakan untuk mengetahui pengaruh suhu inkubasi terhadap waktu penetasan, derajat penetasan telur, serta derajat kelangsungan hidup larva pasca pemaparan suhu pada proses penetasan (suhu air 25$26^{\circ} \mathrm{C}$ ). Penelitian ini menggunakan Rancangan Acak Lengkap (RAL) dengan 3 perlakuan suhu inkubasi berbeda dan 3 kali ulangan. Perlakuan meliputi A kontrol dengan perlakuan suhu ruang (suhu air $25-26^{\circ} \mathrm{C}$ ), perlakuan $\mathrm{B}$ dengan perlakuan suhu $28^{\circ} \mathrm{C}$, perlakuan $\mathrm{C}$ dengan perlakuan suhu $31^{\circ} \mathrm{C}$. Berdasarkan uji Beda Nyata Terkecil (BNT) $(\mathrm{P}<0,05)$ perlakuan $\mathrm{C}$ yang menetas selama 92,23 jam (3 hari 20 jam) dan B yang menetas selama 93,29 jam (3 hari 21 jam) tidak menunjukan perbedaan yang nyata diantara keduanya, namun berbeda nyata dengan perlakuan A yang menetas selama 95,50 jam (3 hari 23 jam). Derajat penetasan telur berdasarkan uji BNT menunjukan perbedaan yang nyata di setiap perlakuan, dimana perlakuan A menghasilkan nilai tertinggi sebesar 95,56\% dan perlakuan C dengan nilai terendah sebesar 66,67\%. Derajat kelangsungan hidup larva berdasarkan uji analisis ragam (ANOVA) $(\mathrm{P}<0,05)$ hasil dari masing-masing perlakuan tidak berpengaruh nyata terhadap perbedaan suhu pasca inkubasi.
\end{abstract}

Kata kunci: brushmouth albino, suhu, telur

Dinna Yuliani, Fia Sri Mumpuni, Muarif. 2020. Pengaruh Perlakuan Suhu yang Berbeda terhadap Waktu Penetasan, Daya Tetas Telur dan Tingkat Kelangsungan Hidup Larva Ikan Brushmouth Albino (Ancistrus cirrhosus). Jurnal Mina Sains 6(1): 1-7.

\section{PENDAHULUAN}

Ikan brushmouth albino Ancistrus cirrhosis merupakan ikan dari jenis sapu-sapu hias yang cukup banyak diminati masyarakat lokal maupun luar negeri. Berdasarkan data
KKP (2015) terjadi peningkatan volume produksi ikan sapu hias pada tahun 2014 sebesar 13 ribu ekor, dari volume produksi sebelumnya di tahun 2013 sebesar 12 ribu ekor. Terjadinya peningkatan volume produksi menggambarkan bahwa kegiatan 
budidaya ikan hias memiliki prospek usaha yang baik kedepannya.

Volume produksi sejalan dengan banyaknya produk yang dihasilkan. Oleh sebab itu semakin tinggi kenaikan volume produksi suatu kegiatan budidaya, maka semakin tinggi pula ikan yang harus dipanen. Meningkatnya volume produksi salah satunya didasari dari banyaknya jumlah permintaan. Namun banyaknya jumlah permintaan kurang bisa dipenuhi para pembudidaya salah satunya disebabkan oleh terbatasnya fasilitas dan biaya produksi untuk mencapai target, sehingga kapasitas produksi tidak sebanding dengan permintaan. Oleh sebab itu pola tanam perlu diterapkan untuk membuat siklus produksi teratur dengan baik. Selain itu, efisiensi waktu kegiatan budidaya juga perlu diperhatikan karena dapat mempengaruhi faktor lain seperti biaya produksi, jumlah produksi, dan lain sebagainya. Menurut Effendi (2012) kegiatan budidaya perikanan merupakan kegiatan ekonomi yang mengarah pada industri dimana memenuhi perinsip tepat waktu, tepat jumlah, tepat mutu, dan tepat harga. Keempat perinsip tersebut saling mempengaruhi satu sama lain. Salah satunya perinsip tepat waktu dimana semakin cepat suatu proses kegiatan budidaya berlangsung maka semakin banyak ikan yang diproduksi dengan tetap menjaga kualitas dan mutu, sehingga dapat menghemat waktu dan menekan biaya produksi.

Kualitas air merupakan salah satu faktor yang mempengaruhi produksi kegiatan budidaya, dimana parameter suhu merupakan parameter yang memiliki keterkaitan kompleks terhadap kualitas air lainnya. Sehingga dapat mempengaruhi pertumbuhan, reproduksi, dan kelangsungan hidup (Muarif, 2016). Suhu dapat mempengaruhi histopatologi ikan (Sumantri et al. 2017), proses fisiologi dan biologi tubuh ikan, dan berperan dalam proses perkembangan embrio pada telur (Putri et al. 2013). Suhu juga dapat mempengaruhi waktu penetasan telur, karena selaput telur akan lebih cepat larut pada suhu yang tinggi dibandingkan pada suhu rendah (Hutagalung et al. 2016). Dapat disimpulkan bahwa penanganan suhu yang baik perlu dilakukan untuk mencapai keberhasilan kegiatan pembenihan baik dari segi kualitas, kuantitas maupun waktu. Oleh sebab itu penelitian ini dilakukan untuk mengefisiensikan waktu yang dibutuhkan dalam proses penetasan dengan menggunakan suhu. Selain waktu penetasan, parameter yang diperhatikan pada penelitian ini yaitu berupa derajat penetasan telur dan derajat kelangsungan hidup larva pasca pemaparan suhu. Kedua parameter tersebut ditunjukkan untuk mengetahui kualitas penetasan maupun larva yang dihasilkan terkait metode peningkatan suhu yang dilakukan, sehingga nantinya didapatkan data suhu yang optimal. Komoditas ini dipilih karena masih sedikit sekali kajian ilmiah mengenai ikan brushmouth albino. Penelitian ini dilaksanakan dengan harapan dapat memberikan informasi kepada masyarakat mengenai besarnya pengaruh suhu dalam kegiatan budidaya khususnya dalam proses penetasan telur.

\section{BAHAN DAN METODE}

\section{Waktu dan Tempat}

Penelitian ini dilaksanakan pada JanuariOktober 2019. Percobaan uji dilaksanakan pada 23 Maret 2019 - 3 April 2019, bertempat di Jl. Jabaru 4 Pasir Kuda Bogor.

\section{Alat dan Bahan}

Peralatan yang digunakan dalam penelitian ini meliputi wadah percobaan berupa akuarium sebanyak 9 unit berukuran $15 \mathrm{~cm} \times 15 \mathrm{~cm}$ x $20 \mathrm{~cm}$, aerator dan sistem aerasi, heater, $\mathrm{pH}$ meter, dan termometer. Bahan yang digunakan dalam penelitian ini meliputi telur ikan brushmouth albino (Ancistrus cirrhosus) dan methylene blue.

\section{Rancangan Penelitian}

Percobaan ini menggunakan Rancangan Acak Lengkap (RAL) sebanyak tiga perlakuan. Perlakuan terdiri dari A kontrol dengan penetasan telur perlakuan suhu ruangan $\left(25-26^{\circ} \mathrm{C}\right)$, perlakuan $\mathrm{B}$ penetasan telur dengan perlakuan suhu sebesar $28^{\circ} \mathrm{C}$ dan perlakuan $\mathrm{C}$ penetasan telur dengan perlakuan suhu sebesar $31^{\circ} \mathrm{C}$. Setiap perlakuan akan 
diberi ulangan sebanyak tiga kali untuk mengurangi kekeliruan dalam penelitian.

Data percobaan RAL di abstrasikan melalui model persamaan linear sebagai berikut;

Dimana:

$$
\mathrm{Y}_{\mathrm{ij}}=\mu+\mathrm{T}_{\mathrm{i}}+\varepsilon_{\mathrm{ij}}
$$

$\mu=$ Nilai tengah populasi

$\mathrm{T}_{\mathrm{i}}=$ Pengaruh aditif (koefisien regresi parsial) dari perlakuan ke-i

$\varepsilon_{\mathrm{ij}}=$ Galat percobaan dari perlakuan ke-I pada pengamatan ke-j

\section{METODE PENELITIAN}

\section{Persiapan Wadah}

Sebelum digunakan, semua wadah percobaan dibersihkan dengan cara menggosok pinggiran akuarium dengan busa lalu dibilas dengan air dan dikeringkan selama 1 hari. Dilakukan pengisian air keesokan harinya pada akuarium percobaan sebanyak 3,3 L dengan ketinggian air sebesar $15 \mathrm{~cm}$. Selanjutnya aerator dan heater dipasang lalu suhu diatur sesuai perlakuan.

\section{Penebaran Telur}

Telur yang ditebar merupakan telur terbuahi yang didapat dari pembudidaya. Telur dipisahkan dan dihitung untuk ditebar berdasarkan perlakuannya. Setiap satuan percobaan ditebar telur sebanyak 30 butir. Selanjutnya dilakukan penebaran telur di masing-masing perlakuan melalui proses aklimasi. Proses aklimasi dilakukan selama 15 menit untuk menyesuaikan kondisi air khususnya suhu air agar telur tidak stress. Keseluruhan percobaan akan membutuhkan telur terbuahi sebanyak 270 butir.

\section{Prosedur Percobaan}

Media penetasan di setiap satuan percobaan diiberi perlakuan obat berupa methylene blue dengan dosis $3 \mathrm{mg} \mathrm{L-1}$ untuk mencegah pertumbuhan jamur pada telur. Selama masa inkubasi, dilakukan pengamatan berdasarkan variabel pengamatan meliputi waktu penetasan, daya tetas telur dan tingkat kelangsungan hidup larva.

\section{Parameter Pengamatan Waktu Penetasan}

Data waktu penetasan telur diperoleh dengan menghitung lama masa pengeraman telur, yaitu dengan cara mencatat waktu penebaran dan waktu menetasnya telur di setiap perlakuan. Pengamatan waktu penetasan dilakukan secara periodik di hari menetasnya telur selama 60 menit sekali dengan cara menghitung jumlah telur yang menetas di waktu tersebut. Data masa waktu pengeraman pada akuarium dihitung rataratanya untuk setiap perlakuan, selanjutnya dilakukan perbandingan.

\section{Derajat Penetasan Telur (HR)}

Pengukuran daya tetas telur (HR) dilakukan pada saat telur menetas yaitu 4-5 hari pasca penebaran. Pengukuran dilakukan dengan cara menghitung jumlah telur yang menetas dibagi dengan jumlah telur yang terbuahi dan dikali seratus persen, hasil dinyatakan dalam persen (\%) dengan menggunakan rumus berikut:

$$
\mathrm{HR}=\frac{\text { Jumlah telur yang menetas }}{\text { Jumlah total telur }} \times 100 \%
$$

\section{Derajat Kelangsungan Hidup Larva (SR)}

Pemeliharaan larva dilakukan selama tujuh hari tanpa perlakuan suhu, sehingga suhu air inkubasi telur setiap perlakuan mengikuti suhu ruang $\left(27-28^{\circ} \mathrm{C}\right)$. Pengukuran tingkat kelangsungan hidup larva (SR) dilakukan dengan cara menghitung jumlah larva pada hari ke tujuh pemeliharaan dibagi dengan jumlah larva awal pasca penetasan, lalu dikali seratus persen dan hasil dinyatakan dalam persen $(\%)$, dihitung dengan menggunakan rumus berikut:

$$
\text { SR larva }=\frac{\text { Jumlah ikan pada akhir }}{\text { Jumlah ikan pada awal }} \times 100 \%
$$

\section{Parameter Penunjang Parameter Kualitas Air}

Kualitas air pada media inkubasi diukur dengan parameter meliputi $\mathrm{pH}$ dengan menggunakan $\mathrm{pH}$ meter, oksigen terlarut (DO) dengan menggunakan DO meter, dan suhu dengan menggunakan termometer. 


\section{Analisis Data}

Data yang telah diperoleh selanjutnya dianalisis menggunakan ANOVA (Analisis Ragam). Perbedaan yang nyata antar perlakuan selanjutnya akan dilakukan uji lanjut dengan menggunakan metode BNT (Beda Nyata Terkecil).

\section{HASIL DAN PEMBAHASAN}

\section{Hasil}

Waktu Penetasan Telur

Hasil penelitian yang telah dilakukan menunjukan bahwa waktu penetasan telur pada perlakuan $\mathrm{C}$ menetas lebih cepat dibandingkan dengan kedua perlakuan lainnya, yaitu selama 92,23 jam (3 hari 20 jam). Diikuti telur dengan perlakuan B yang menetas selama 93,29 jam (3 hari 21 jam) dan telur dengan perlakuan A menetas selama 95,50 jam (3 hari 23 jam). Hasil uji $F$ menunjukan adanya pengaruh yang nyata antara waktu penetasan telur dengan perlakuan suhu yang berbeda. Hasil uji BNT menunjukan perlakuan $\mathrm{C}$ menghasilkan waktu penetasan tercepat dibanding perlakuan lainnya. Data dapat dilihat pada Tabel 1.

Tabel 1 Waktu Penetasan Telur Terhadap Perlakuan Suhu

\begin{tabular}{cccc}
\hline \multirow{2}{*}{ Ulangan } & \multicolumn{3}{c}{ Perlakuan } \\
\cline { 2 - 4 } & $\begin{array}{c}\text { Kontrol } \\
(\text { Jam })\end{array}$ & $\begin{array}{c}28^{\circ} \mathrm{C} \\
(\text { Jam })\end{array}$ & $\begin{array}{c}31^{\circ} \mathrm{C} \\
(\mathrm{Jam})\end{array}$ \\
\hline 1 & 94,23 & 93,33 & 91,78 \\
2 & 97,50 & 93,45 & 92,36 \\
3 & 94,78 & 93,10 & 92,56 \\
\hline Rata-Rata & $95,50^{\mathrm{a}}$ & $93,29^{\mathrm{b}}$ & $92,23^{\mathrm{b}}$
\end{tabular}

Keterangan: Angka yang diikuti oleh huruf yang sama menunjukkan hasil uji yang tidak berbeda nyata $(\mathrm{P}<0,05)$

Derajat Penetasan Telur

Derajat penetasan telur tertinggi terjadi pada perlakuan A yaitu sebesar $95,56 \%$. Diikuti telur pada perlakuan B dengan derajat penetasan telur sebesar $75,56 \%$ dan perlakuan $\mathrm{C}$ menghasilkan derajat penetasan terendah yaitu sebesar 66,67\%. Hasil uji F menunjukan adanya pengaruh yang nyata antara derajat penetasan telur dengan perlakuan suhu. Sedangkan hasil uji BNT menunjukan bahwa perlakuan A menghasilkan derajat penetasan tertinggi. Data dapat dilihat pada Tabel 2.

Tabel 2 Derajat Penetasan Telur Terhadap Perlakuan Suhu

\begin{tabular}{cccc}
\hline \multirow{2}{*}{ Ulangan } & \multicolumn{3}{c}{ Perlakuan } \\
\cline { 2 - 4 } & Kontrol $(\%)$ & $28^{\circ} \mathrm{C}(\%)$ & $31^{\circ} \mathrm{C}(\%)$ \\
\hline 1 & 96,67 & 73,33 & 60,00 \\
\hline 2 & 96,67 & 76,67 & 73,33 \\
\hline 3 & 93,33 & 76,67 & 66,67 \\
\hline Rata-Rata & $95,55^{\mathrm{a}}$ & $75,55^{\mathrm{b}}$ & $66,66^{\mathrm{c}}$ \\
\hline
\end{tabular}

Keterangan: Angka yang diikuti oleh huruf yang sama menunjukkan hasil uji yang tidak berbeda nyata $(\mathrm{P}<0,05)$

Derajat Kelangsungan Hidup Larva

Derajat kelangsungan hidup larva pada perlakuan A menghasilkan nilai tertinggi dibanding perlakuan lainnya, yaitu sebesar 95,40\%. Diikuti larva pada perlakuan B dengan derajat kelangsungan hidup sebesar 94,07\% dan perlakuan C menghasilkan derajat kelangsungan hidup terendah yaitu sebesar 91,26\%. Hasil uji F menunjukan tidak adanya pengaruh yang nyata antara derajat kelangsungan hidup larva terhadap paparan suhu pada fase inkubasi telur. Data dapat dilihat pada Tabel 3. 
Tabel 3 Derajat Kelangsungan Hidup Larva Pasca Perlakuan Suhu

\begin{tabular}{cccc}
\hline \multirow{2}{*}{ Ulangan } & \multicolumn{3}{c}{ Perlakuan } \\
\cline { 2 - 4 } & Kontrol $(\%)$ & $28^{\circ} \mathrm{C}(\%)$ & $31^{\circ} \mathrm{C}(\%)$ \\
\hline 1 & 89,65 & 90,90 & 83,33 \\
\hline 2 & 96,55 & 100 & 95,45 \\
\hline 3 & 100 & 91,30 & 95 \\
\hline Rata-rata & 95,40 & 94,07 & 91,26 \\
\hline
\end{tabular}

\section{Pembahasan \\ Waktu Penetasan Telur}

Salah satu faktor luar yang dapat mempengaruhi masa pengeraman yaitu suhu. Suhu inkubasi sangat mempengaruhi laju perkembangan embrio (Yang et al. 2015) dan aktivitas enzim penetasan (Farida et al., 2016). Hasil penelitian ini sesuai dengan penelitian yang dilakukan oleh Pangreksa et al. (2016), yang membuktikan bahwa suhu mempengaruhi waktu penetasan telur ikan sinodontis Synodontis eupterus dengan penetasan tercepat terjadi pada suhu $31-32^{\circ} \mathrm{C}$ selama 1120 menit (18 jam 40 menit), dengan perlakuan kontrol berlangsung selama 1340 menit (22 jam 20 menit). Beberapa penelitian yang diuji pada spesies lain seperti ikan kakap putih Lates calcariver, ikan betok Anabas testudineus, dan ikan gurame Osphronemus gouramy juga menghasilkan kesimpulan yang sama (Hasibuan et al. 2018; Putri et al. 2013; Pratama et al. 2018), bahwa suhu mempengaruhi waktu penetasan telur dimana semakin tinggi suhu maka semakin cepat telur menetas. Penetasan telur berlangsung melalui beberapa proses, dimana proses pelunakan cangkang chorion (choriolisis) oleh enzim merupakan proses yang terakhir dan esensial (Yamagami, 1981). Yamagami (1988) menjelaskan bahwa proses enzimatik tersebut terjadi berdasarkan 2 tahapan, yaitu sekresi enzim oleh sel kelenjar penetasan dan choriolisis. Setelah enzim chorionase disekresikan, proses choriolisis dimulai dari bagian terdalam cangkang chorion (sisi ruang periviteline). Enzim chorionase mencerna lapisan terdalam chorion dengan cara menghidrolisis beberapa ikatan peptida dari protein penyusunnya untuk memisahkannya menjadi dua kelompok glikoprotein yang larut dalam air. Baik proses sekresi enzim maupun choriolisis, keduanya dipengaruhi oleh suhu. Suhu dapat menstimulasi sekresi enzim chorionase dan ketika choriolisis berlangsung, aktivitasnya akan meningkat seiring dengan meningkatnya suhu. Suhu juga dapat mempengaruhi jumlah dan ukuran sel kelenjar endodermal yang mempengaruhi jumlah enzim chorionase yang dihasilkan (Zarski et al. 2017), sehingga cangkang chorion lebih cepat melunak dan mempengaruhi waktu penetasan. Proses choriolisis sendiri membutuhkan waktu cukup singkat untuk melebur sebagian besar bagian dalam cangkang chorion, yang terjadi pada ikan medaka Oryzias latipes selama \pm 30 menit pada suhu $30^{\circ} \mathrm{C}$. Uji kerja enzim penetasan yang dilakukan Yamagami (1981) yaitu dengan cara mengisolasi cangkang telur dan diinkubasi dengan enzim chorionase murni. Hasilnya lebih dari $90 \%$ cangkang yang melunak dalam waktu 1-1,5 jam pada suhu $30^{\circ} \mathrm{C}$.Berdasarkan hasil penelitian, rentan waktu penetasan antar perlakuan berjarak selama 1-2 jam, sehingga memungkinkan jika terjadinya perbedaan waktu penetasan telur di setiap perlakuan suhu disebabkan oleh aktivitas enzim penetasan. Sesuai dengan pernyataan Zarski et al. 2017 pada paragraf sebelumnya, memungkinkan bahwa cepatnya telur ikan brushmouth albino menetas pada suhu tinggi diakibatkan oleh suhu yang mempengaruhi jumlah dan ukuran sel kelenjar enzim penetasan telur, sehingga selain suhu yang dapat mempengaruhi kerja enzim, dua hal tersebut juga menyumbang peran dalam percepatan proses kerja enzim dalam mencerna chorion menjadi lunak.

\section{Derajat Penetasan Telur}

Hasil penelitian menunjukan bahwa peningkatan suhu menurunkan derajat 
penetasan telur ikan brushmouth albino. Sesuai dengan hasil penelitian dengan metode yang sama pada ikan sinodontis Synodontis eupterus, daya tetas telur tertinggi pada ikan sinodontis terjadi pada perlakuan suhu inkubasi $25-26^{\circ} \mathrm{C}$ yaitu sebesar $94,67 \%$ dibandingkan dengan perlakuan suhu lainnya yaitu $28-29^{\circ} \mathrm{C}, \quad 31-32^{\circ} \mathrm{C}$ dan kontrol (Pangreksa et al. 2016). Kucharczyk et al. (1997) menyatakan bahwa nilai derajat penetasan telur dipengaruhi oleh suhu, dimana nilai derjat penetasan yang tinggi akan dihasilkan jika suhu inkubasi telur sama dengan kisaran suhu pada saat pemijahan. Hal tersebut dikarenakan kisaran suhu optimal untuk perkembangan embrio memiliki korelasi dengan suhu ketika pemijahan berlangsung. Sehingga memungkinkan jika rendahnya derajat penetasan telur ikan brushmouth albino pada perlakuan suhu $31^{\circ} \mathrm{C}$ disebabkan oleh adanya perubahan suhu ketika pemijahan dan inkubasi. Sehingga memungkinkan telur kurang bisa beradaptasi pada suhu inkbasi karena rentang suhu yang tinggi, dimana pada saat pemijahan suhu air berkisar antara $24-25^{\circ} \mathrm{C}$.

Suhu hingga mencapai level mematikan bervariasi berdasarkan tingkat adaptasi suatu organisme di tiap fase hidupnya (Blaxter, 1969). Sedangkan embrio memiliki batas toleransi suhu dalam proses perkembangannya. Pada fase perkembangan embrionik, rentang toleransi suhu lebih kecil dibandingkan pada fase hidup lainnya di sebagian besar spesies ikan. Di alam, rentang suhu yang dapat ditoleransi telur untuk spesies ikan yang hidup di iklim sedang hingga tropis sebesar $\pm 5,8^{\circ} \mathrm{C}$ (Rombough, 1997). Faktor utama rendahnya rentang suhu toleransi pada fase embrionik ialah karena ketidakmampuan embrio untuk menyesuaikan diri dalam mengompensasi suhu. Embrio tidak dapat mengatur fluiditas membran selnya, dan pada tingkat metabolismenya pun tidak menunjukkan adanya tanda-tanda aklimasi suhu (Rombough 1997). Yani et al. (2017) berdasarkan hasil penelitiannya menyatakan bahwa rendahnya derajat penetasan telur pada suhu tinggi $\left(32^{\circ} \mathrm{C}\right)$ disebabkan oleh terhambatnya perkembangan embrio, sehingga terjadi kematian di fase gastrula akhir. Nilai suhu inkubasi yang terlalu rendah atau terlalu tinggi dapat menyebabkan perkembangan embrionik yang tidak tepat, sehingga dapat menyebabkan kelainan perkembangan atau bahkan dapat terjadi kematian pada embrio (Zarski et al. 2017).

\section{Derajat Kelangsungan Hidup Larva}

Berdasarkan hasil perhitungan uji $\mathrm{F}$, perlakuan suhu inkubasi telur yang berbeda tidak mempengaruhi derajat kelangsungan hidup larva. Berdasarkan hasil, derajat kelangsungan hidup larva perlakuan C mengasilkan derajat kelangsungan hidup terendah yaitu sebesar 91,26\%, dibandingkan dengan perlakuan A yang menghasilkan derajat kelangsungan hidup tertinggi yaitu sebesar 95,40\%. Brysiewicz et al. (2011) melaporkan bahwa ikan dari genus Ancitrus dapat bereproduksi pada kondisi suhu sebesar $24^{\circ} \mathrm{C}$. Sedangkan suhu pemeliharaan larva mencapai $25^{\circ} \mathrm{C}$. Hal itu membuktikan bahwa tingginya nilai derajat kelangsungan hidup larva pada ke-3 perlakuan uji memungkinkan disebabkan oleh kondisi lingkungan yang sesuai dengan habitatnya, dengan nilai DO sebesar 6,1-6,2 mg/L. Kesesuaian kondisi lingkungan perlakuan uji dengan habitatnya juga dapat membuktikan bahwa kondisi tersebut berada pada tingkat yang di toleransi oleh larva. Sehingga dapat disimpulkan bahwa perlakuan suhu inkubasi pada proses penetasan telur tidak mempengaruhi derajat kelangsungan hidup larva.

\section{KESIMPULAN DAN SARAN}

\section{Kesimpulan}

Hasil peneitian menunjukan, waktu penetasan tercepat terjadi pada perlakuan suhu $31^{\circ} \mathrm{C}$ yaitu selama 92,23 jam, sedangkan waktu penetasan terpanjang terjadi selama 95,50 jam pada perlakuan kontrol. Derajat penetasan telur tertinggi terjadi pada perlakuan kontrol sebesar 95,55\% dan derajat penetasan telur terendah terjadi pada perlakuan $31^{\circ} \mathrm{C}$ sebesar $66,66 \%$. Pemaparan suhu pada pada proses inkubasi telur tidak 
menghasilkan pengaruh yang nyata terhadap derajat kelangsungan hidup larva.

\section{Saran}

Diharapkan agar kedepannya penelitian ini bisa lebih dikembangkan dengan memperbanyak perlakuan suhu dan variabel pengamatan. Seperti embriogenesis dan tingkat abnormalitas larva agar dapat dikaji lebih spesifik.

\section{DAFTAR PUSTAKA}

Blaxter J H S. 1969. Chapter 4-Development: Eggs and Larvae. Academic press Inc. 3:177-252.

Brysiewicz A, J Szulc, K Formicki, A Tański, A Korzelecka-Orkisz. 2011. The structure and the embryogenetic role of eggs and egg membranes of Ancistrus dolichopterus (Actinopterygii: Siluriformes: Loricariidae). Acta Ichthyologica et Piscatoria. 41(3):223227.

Farida, Rachimi, Adrianus. 2016. Pengaruh suhu yang berbeda terhadap penetasan dan kelangsungan hidup larva ikan biawan (Helostoma temmincki). Jurnal Ruaya. 4(2):63-69.

Hasibuan R B, Irawan H, Yulianto T. 2018. Pengaruh suhu terhadap daya tetas telur ikan kakap putih (Lates calcarifer). Intek Akuakultur. 2(2):49-57.

Hutagalung J, Alawi H. 2016. Pengaruh suhu dan oksigen terhadap penetasan telur dan kelulushidupan awal larva ikan pawas (Osteochilus hasselti CV). Jurnal Online Mahasiswa (JOM) Bidang Perikanan dan Ilmu Kelautan. 4(1):1-13.

[KKP] Kementrian Kelautan dan Perikanan. 2015. Kelautan dan Perikanan Dalam Angka Tahun 2015. Jakarta:KKP.

Kucharczyk D, Luczynski M, Kujawa R, Czerkies P. 1997. Effect of temperature on embryonic and larval development of bream (Abramis brama L.). Aquatic Sciences. 214-224.

Muarif. 2016. Karakteristik suhu perairan di kolam budidaya perikanan. Jurnal Mina Sains. 2(2):96-101.
Pangreksa A, Mustahal, Indaryanto F R, Nur B. 2016. Pengaruh perbedaan suhu inkubasi terhadap waktu penetasan dan daya tetas telur ikan sinodontis (Synodontis eupterus). Jurnal Perikanan dan Kelautan. 6(2):147-160.

Pratama, B A, Susilowati T, Yuniarti T. 2018. Pengaruh perbedaan suhu terhadap lama penetasan telur, daya teteas telur, kelulushidupan dan pertumbuhan benih ikan gurame (Osphronemus gouramy) strain bastar. Jurnal Sains Akuakultur Tropis. 2(1):59-65.

Putri D A, Muslim, Fitrani M. 2013. Presentase penetasan telur ikan betok (Anabas testudineus) dengan suhu inkubasi yang berbeda. Jurnal Akuakultur Rawa Indonesia. 1(2):184-191.

Rombough P J. 1997. The effect of temperature on embryonic and larval development. In: Global Warming: Implications for Freshwater and Marine Fish. Ontario: Cambridge University Press.

Sumantri A, Mulyana, Mumpuni F S. 2017. Pengaruh perbedaan suhu pemeliharaan terhadap hidtopatologi insang dan kulit ikan komet (Carassius auratus). Jurnal Mina Sains. 2(1):1-7.

Yamagami K. 1981. Mechanism of haching in fish: secretion of hatching enzyme and enzymatic choryolisis. Amer Zool. 21:459-471.

Yamagami K. 1988. Fish physiology; 7. Mechanisms of Hatching in Fish. Academic press. 11(A):447-499.

Yang Z, Chen Y. 2005. Effect of temperature on incubation period and hatching success of obscure Takifugu obscurus (Abe) eggs. Aquaculture. 246:173-179.

Yani A, Wamnebo M I. 2017. Pengaruh suhu yang berbeda terhadap tingkat penetasan telur ikan kerapusunu (Plactropomus leopardus). Jurnal Airaha. 6(1):018-021.

Żarski D, Horváth A, Bernáth G, Krejszeff S, Radóczi J, Palińska-Żarska K, Bokor K, Kupren K, Urbányi B. 2017. Controlled reproduction of wild eurasian perch $A$ Hatchery manual. Switzerland: Springer International Publishing AG. Hlm. 81-89. 